Int. J. Electrochem. Sci., 11 (2016) $4619-4631$

International Journal of

ELECTROCHEMICAL

SCIENCE

WWw.electrochemsci.org

\title{
Determination of Hydrazine in Various Water Samples by Square Wave Voltammetry with Zinc-Layered Hydroxide-3(4- methoxyphenyl) Propionate Nanocomposite Modified Glassy Carbon Electrode
}

\author{
Illyas Md Isa ${ }^{1,2, *}$, Syahella Saruddin ${ }^{1}$, Norhayati Hashim ${ }^{1,2}$, Mustaffa Ahmad $^{1}$, Sulaiman Ab Ghani ${ }^{3}$ \\ ${ }^{1}$ Department of Chemistry, Faculty of Science and Mathematics, Universiti Pendidikan Sultan Idris, \\ 35900 Tanjong Malim, Perak, Malaysia \\ ${ }^{2}$ Nanotechnology Research Centre, Faculty of Science and Mathematics, Universiti Pendidikan Sultan \\ Idris, 35900 Tanjong Malim, Perak, Malaysia \\ ${ }^{3}$ Pusat Pengajian Sains Kimia, Universiti Sains Malaysia, 11900 USM Pulau Pinang, Malaysia \\ *E-mail: illyas@fsmt.upsi.edu.my
}

doi: $10.20964 / 2016.06 .59$

Received: 30 December 2015 / Accepted: 15 February 2016 / Published: 4 May 2016

The application of zinc-layered hydroxide-3(4-methoxyphenyl) propionate (ZLH-MPP) nanocomposite as a suitable mediator in a voltammetric sensor for the determination of hydrazine by square wave voltammetry (SWV) were evaluated. The ZLH-MPP modified glassy carbon electrode exhibited a good sensitivity in $0.7 \mathrm{M} \mathrm{Na}_{2} \mathrm{SO}_{4}, \mathrm{pH} 10.0$ and using square wave parameter of $120 \mathrm{~Hz}$ frequency, $25 \mathrm{mV}$ pulse size and $3 \mathrm{mV}$ step size. The $\mathrm{SWV}$ response showed a linear dependence of the peak current to the concentration in the range of $1.0 \times 10^{-6}-1.0 \times 10^{-4} \mathrm{M}$ hydrazine with limit of detection $6.7 \times 10^{-7} \mathrm{M}$ and correlation coefficient of 0.9966 . The presence of 200 fold of metal ions and 500 fold organic substances in excess to the concentration of hydrazine did not interfere. Electrochemical impedance spectroscopy showed that the charge transfer at the electrode-solution interface was favourable. The proposed electrode was applied for the recovery of the real samples studies by using standard addition method.

Keywords: glassy carbon electrode, hydrazin, hydroxide-3(4-methoxyphenyl) propionate, square wave voltammetry

\section{$\underline{\text { FULL TEXT }}$}

(C) 2016 The Authors. Published by ESG (www.electrochemsci.org). This article is an open access article distributed under the terms and conditions of the Creative Commons Attribution license (http://creativecommons.org/licenses/by/4.0/). 